\title{
THE ANALYSIS OF INDICATORS OF LONG-TERM PROSPERITY COMPANIES FROM AUTOMOTIVE BASED ON PREDICTIVE FINANCE INDICATORS
}

\author{
Hana Scholleová \\ Czech Technical University, Prague, MIAS School of Business \& Interdisciplinary Studies
}

\begin{abstract}
Automotive industry in the Czech Republic is important and highly monitored. The reason for this is mainly the fact that the automotive industry contributes significantly to the formation of GDP, according to Ministry of Industry and Trade (MIT, 2015) 15\% long-term profit is made in the automotive sector. This sector also creates large numbers of jobs. This article aims to test ex post leading financial indicators of long-term prosperity, which have previously been selected from a large set of indicators. Their influence was observed in comparison with the value of ROA created two years thereafter on a large group of manufacturing companies, whose activities and position in the industry in the Czech Republic are similar. Past of the success was the creation of economic value added as financial assumption of long-term prosperity. In this article we try to indicate the importance of selected indicators for automotive industry. Furthermore, we show portability in time, i.e. that the same indicators correlate with the value of ROA and with a distance longer or shorter time in advance. The tested set includes 186 Czech automotive companies, which were excluded from Tier 1 companies because their market conditions are qualitatively higher.
\end{abstract}

Keywords: indicators, finance, long-term prosperity, automotive

JEL code: D92, G17, G32

\section{Introduction}

The Czech Republic annually produces 118 cars per 1000 inhabitants and is among the world's automotive powers. With an annual production of over 1.2 million cars it ranks 16th in the world (in 2014 production reached a record of 1,278,000 vehicles). Czech automotive sector employs more than 150,000 people. Automotive constitute more than 20\% of Czech manufacturing industry, as well as Czech exports. Besides the three major automobile companies (Skoda, Hyundai, and TPCA), bus manufacturers (IVECO, SOR) and trucks (AVIA, TATRA, ZETOR), this sector includes an extensive network of suppliers. Suppliers of total sales account for more than two fifths and employ more than two thirds of people in the industry. Total sales industry in 2014 reached nearly trillion CZK. (AIA, 2015) The industry is cyclical, which is not good for the Czech Republic. Any wobble in the sector is monitored with concern because it means the impact of both GDP and employment effects. It is therefore obvious that the prosperity of businesses in the automotive sector has a greater reach. The aim of this article is to analyze the financial indicators that are significant for the long-term prosperity of the company in the industry. Also, watch their distinct and common characteristics depending on the success of firms and distance evaluation. The analysis focuses on firms in the sectors of automotive, Sector 29 by CZ-NACE (Czech Statistical organization, 2016).

\section{Competitiveness, long term success and financial indicators}

There are three basic reference competitiveness levels - national, corporate and system between them as so mezzo-level and highlights the need for different approaches to competitiveness at different levels. When focusing on the corporate level, even here it is possible to define the concept of competitiveness considerably differently. Porter's competitiveness is the ability of 
the organization that produces values to face 5 driving forces of competition - customers, suppliers, competitors, potential competitors and substitutes). The purpose of this approach is to analyze and evaluate the impact of the production system and resistance against the competitive forces in the value-chain on partial processes, which add to the product as a specific measurable value EVA - Economic Value Added (Porter, 1996).

Economic Value Added (EVA) is defined as

$\mathrm{EVA}=\mathrm{NOPAT}-\mathrm{C} \times \mathrm{WACC}$

where

NOPAT is Net Operating Profit after Tax,

C Firm Capital,

WACC Cost of Capital.

A successful long-term firm creates value, therefore EVA $>0$, ie.

NOPAT $>$ C $\times$ WACC

or

NOPAT / C > WACC

Because of non-financial firms should apply that

EBIT > NOPAT, then it is possible to use the previous rule, so that if ROA > WACC,

then also NOPAT / C will be greater than WACC and thus in case of ROA > WACC company creates economic value added.

The financial performance of the company's competitiveness existence may therefore be an indicator ROA, respectively its value being greater than WACC.

Klečka (2013) used the EVA for finding the best of financial indicators for productivity too.

While it is clear that the financial results are rather the result, it is clear that they are also a good basis for further development and competitiveness can be perceived as such, as (Foltýn 2001) attempts to prove on a group of firms.

(Scholleová, Č́mská, 2015) have been tested, whether a number of commonly used indicators selected by us (especially the character of the growth), has an impact on the competitiveness of firms in terms of economic value creation (for manufactory industry).

The set of indicators can be divided into several groups:

1) indicators, which are monitored as basic indicators of senior corporate success and are the expected long-term prosperity - in terms of ROE, ROA, ROS, PR, g,

2) indicators, which are a prerequisite for concentration on core business, on its own operations and thus building permanent competitive advantage - sufficient productivity, secure financing of long and short field, skilled labour, subcontracting,

3 ) indicators showing flexible readiness to work with risk - corporate work with operating and financing leverage,

4) growth indicators aimed at monitoring changes in the business and at the same time results of development.

ROC curve analysis results (Scholleova, Čámská, 2015) are included in Table 1; indicators are sorted by level of importance. 
Table 1. Significant indicators

\begin{tabular}{|l|l|l|}
\hline Indicator & Of short & Explanation \\
\hline Operation expensiveness & OE/OR & $\begin{array}{l}\text { the ratio of operating expenses to } \\
\text { operating revenues }\end{array}$ \\
\hline Return on Assets & ROA & $\begin{array}{l}\text { earnings before interest and taxes divided } \\
\text { by assets }\end{array}$ \\
\hline Return on Sales & ROS & $\begin{array}{l}\text { earnings after taxes divided by operating } \\
\text { revenues }\end{array}$ \\
\hline Return on Equity & ROE & earnings after taxes divided by equity \\
\hline Productivity & VA/PE & value added divided by personal expenses \\
\hline Growth of Value Added & I(VA) & annual growth of value added \\
\hline Effect of Financial Leverage & FL & (ROE -ROA*(1 - tax)) \\
\hline $\begin{array}{l}\text { Growth of Amortization and } \\
\text { Depreciation }\end{array}$ & I(AD) & $\begin{array}{l}\text { annual growth of amortization and } \\
\text { depreciation }\end{array}$ \\
\hline Growth of Personal Expenses & I(PE) & annual growth of personal expenses \\
\hline Growth of Sales & I(S) & annual growth of operating revenues \\
\hline Growth of Total Assets & I(TA) & annual growth of total assets \\
\hline Sustainable growth rate & $\mathrm{g}$ & ROE multiplied by plowback ratio \\
\hline
\end{tabular}

Source: own processing according to (Scholleová, Č́ámská 2015)

The table 1 displays all variables which are significant as well as with high discriminatory power. The variables are listed according to the value of Area (alternatively AuROC coefficient). The higher value indicates a better explanatory power. It means in a practical sense that the higher values of all indicators except ratio of operating costs divided by operating sales indicate a strong correlation that evaluated business unit could be successful/competitive. In the case of the ratio operating costs to operating sales this state is indicated by smaller values. The best results are obtained by indicators as ratio of operating costs divided by operating sales and common profitability ratios ROA, ROE and ROS. On the other hand, the lowest explanatory power is connected with annual growth of total assets and sustainable growth rate because the area does not exceed $60 \%$. In the middle of these indicators are value added divided by personal expenses, growth of value added, financial leverage, growth of amortization and depreciation, growth of personal expenses and growth of total assets.

\section{Methods and Results}

This article aims to find out the previous behavior of significant indicators of long-term prosperity in similar industries - automotive. For this purpose, data analyzed 186 companies that were obtained from the Albertina database. There should be all the annual reports of all companies in the country.

The analyzed group are companies which are included in the CZ NACE 29 Manufacture of motor vehicles (excluding motorcycles), trailers, semi-trailers, which include subgroups 29.1 Manufacture of motor vehicles and their engines and 29.2 Manufacture of bodies for motor vehicles; manufacture of trailers and semi-trailers 29.3 Manufacture of parts and accessories for motor vehicles and their engines.

From the input file were excluded for lack of credibility entities, whose annual personnel costs were less than 2.5 miles CZK.

The contemporary automotive industry is typified by vertically integrated production networks organized by large lead assembly firms, in which the majority of components production is outsourced to independent suppliers (Sturgeon et al., 2008). Companies automotive industry 
can be classified into groups of Tier 1, Tier 2 and Tier 3. A tier one company is the most important member of a supply chain, supplying components directly to the original equipment manufacturer (OEM) that set up the chain. Creating a tiered supply chain is part of supply chain management. Its aim is to link important business functions and processes in the supply chain into an integrated business model. In a typical supply chain, tier two companies supply companies in tier one; tier three supplies tier two, and so on. Tiered supply chains are common in industries such as aerospace or automotive manufacturing where the final product consists of many complex components and sub-assemblies that must comply with stringent quality, manufacturing and business standards.

Automotive Industry Association (AIA, 2016) states, that in the Czech Republic 13 companies belong to Tier 1, which have a different character than the loss of their suppliers (AGADOS, EKOBUS, HYUNDAI MOTOR MANUFACTURING CZECH, Iveco Czech Republic, JAWA, MTX, PANAV, SCHWARZMÜLLER, SOR Libchavy, ŠKODA AUTO, TATRA TRUCKS, TPCA Czech, ZEBRA GROUP). These companies are more influenced directly or indirectly by foreign markets (capital, customers, etc.). These companies were from the file also rejected, we will pursue only companies belonging to Tier 2 and Tier 3 and their entire time series from 2010 to 2014.

Because many of the indicators are growth indicators, we will work with the results of the indicators for 2011-2014.

Criterion for the success of the company in the first evaluation will ROA = EBIT / Assets. According to the value of ROA in 2014, companies are divided into 4 groups:

A) Companies whose ROA $>$ WACC, so very likely to produce EVA.

B) Companies whose ROA $>$ risk free rate, but ROA $<$ WACC.

C) Companies that have a profit, but ROA <risk free rate.

D) companies that have EBIT and ROA $<0$.

The question is what values to use for the Czech Republic in 2014 and for the automotive industry as an adequate value for WACC and rf.

Table 2. Values applicable to the objective value of ROA

\begin{tabular}{|l|l|l|l|}
\hline Variable & Value & Target group & \\
\hline WACC & $7,27 \%$ & CZ NACE 29, 2014 & \\
\hline rf & $1,58 \%$ & CZ NACE 29, 2014 & \\
\hline WACC & $12,58 \%$ & Auto Parts, Europa, 2014 & \\
\hline WACC & $7,65 \%$ & Auto \& Truck, Europa, 2014 & Not relevant (Tier 1) \\
\hline rf & $2,17 \%$ & Europa, 2014 & \\
\hline WACC & $8,2 \%$ & Auto Parts, USA, 2014 & \\
\hline WACC & $5,09 \%$ & Auto \& Truck, USA, 2014 & Not relevant (Tier 1) \\
\hline rf & $3,389 \%$ & Czech National Bank, 2014 & Maximum in 2014 \\
\hline
\end{tabular}

Source: own processing with public data from (Czech National Bank, 2016) and Damodaran (2016)

Based on the above input data, we decided as the value of the WACC for the automotive industry in the Czech Republic for 2014 to use a value of 10\% (average of the relevant values) and rf value of $2.4 \%$ as an average of the higher values corresponding to at least risk free revenue. The selected criteria set divided into 4 groups, whose size characterizes Table 3 . 
Table 3. Groups of companies according to ROA in 2014

\begin{tabular}{|l|l|r|r|}
\hline Group & Requirement & Share of companies 2014 & Average of ROA 2014 \\
\hline A & EVA $>0$, ROA $>$ WACC & $48 \%$ & $20,2 \%$ \\
\hline B & EVA $<0$, ROA $>$ rf & $31 \%$ & $6,0 \%$ \\
\hline C & EVA $<0$, ROA $<$ rf & $12 \%$ & $1,4 \%$ \\
\hline D & EBIT $<0$ & $8 \%$ & $-7,6 \%$ \\
\hline
\end{tabular}

Source: own processing

In table 4 it can be seen in some leading indicators clear and direct effect - in all the years is rated order from best to worst as the critical (rated) 2014 values sharpen (indicator OE / OR, ROE, ROS, VA / PE). For other indicators, the impact is not so obvious, especially where there is dependence on debt (ROE, FL) or the effects of spending may delay more (I (AD), I (PE)). Indicator growth potential g shows regularly highest values for group $\mathrm{B}$, ie one that does not form value, but is higher than the minimum ROA yield rf.

Table 4. Average values of significant indicators of individual groups in the years before 2014

\begin{tabular}{|c|c|c|c|c|c|c|c|c|c|c|c|c|c|}
\hline $\mathrm{Y}$ & Gr. & OE/OR & ROA & ROS & ROE & VA/PE & $\mathrm{I}(\mathrm{VA})$ & FL & $\mathrm{I}(\mathrm{AD})$ & $\mathrm{I}(\mathrm{PE})$ & $\mathrm{I}(\mathrm{S})$ & $\mathrm{I}(\mathrm{TA})$ & $\mathrm{g}$ \\
\hline \multirow{4}{*}{$\overrightarrow{\bar{\sigma}}$} & $\mathrm{A}$ & 0.94 & $7 \%$ & $6 \%$ & $61 \%$ & 1.96 & 1.17 & $55 \%$ & 1.09 & 1.17 & 1.21 & 1.17 & $2 \%$ \\
\hline & B & 0.97 & $7 \%$ & $2 \%$ & $20 \%$ & 1.47 & 1.30 & $14 \%$ & 1.09 & 1.22 & 1.23 & 1.12 & $11 \%$ \\
\hline & $\mathrm{C}$ & 0.99 & $4 \%$ & $0 \%$ & $10 \%$ & 1.45 & 1.18 & $7 \%$ & 1.87 & 1.12 & 1.26 & 1.15 & $-7 \%$ \\
\hline & $\mathrm{D}$ & 0.99 & $2 \%$ & $1 \%$ & $3 \%$ & 1.33 & 1.12 & $2 \%$ & 0.97 & 1.11 & 1.53 & 1.19 & $3 \%$ \\
\hline \multirow{4}{*}{ 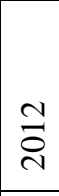 } & A & 0.93 & $12 \%$ & $6 \%$ & $25 \%$ & 1.89 & 1.07 & $15 \%$ & 1.08 & 1.08 & 1.06 & 1.11 & $13 \%$ \\
\hline & $\mathrm{B}$ & 0.96 & $7 \%$ & $3 \%$ & $11 \%$ & 1.47 & -0.18 & $5 \%$ & 1.09 & 1.08 & 1.07 & 1.09 & $22 \%$ \\
\hline & $\mathrm{C}$ & 0.99 & $3 \%$ & $1 \%$ & $-1 \%$ & 1.25 & 0.95 & $-3 \%$ & 1.10 & 1.05 & 1.08 & 1.01 & $9 \%$ \\
\hline & $\mathrm{D}$ & 1.02 & $0 \%$ & $-2 \%$ & $-8 \%$ & 1.29 & 1.07 & $-8 \%$ & 1.05 & 1.01 & 1.05 & 1.01 & $-20 \%$ \\
\hline \multirow{4}{*}{ 羕 } & $\mathrm{A}$ & 0.92 & $14 \%$ & $8 \%$ & $54 \%$ & 1.95 & 0.99 & $43 \%$ & 1.04 & 1.06 & 1.09 & 1.16 & $-2 \%$ \\
\hline & $\mathrm{B}$ & 0.97 & $5 \%$ & $3 \%$ & $14 \%$ & 1.49 & 1.09 & $10 \%$ & 1.08 & 1.08 & 1.11 & 1.13 & $9 \%$ \\
\hline & $\mathrm{C}$ & 1.00 & $1 \%$ & $0 \%$ & $-20 \%$ & 1.37 & 1.42 & $-21 \%$ & 1.44 & 1.13 & 1.14 & 1.35 & $-82 \%$ \\
\hline & $\mathrm{D}$ & 1.04 & $-6 \%$ & $-4 \%$ & $12 \%$ & 1.21 & 1.04 & $17 \%$ & 2.07 & 1.06 & 1.08 & 1.06 & $12 \%$ \\
\hline
\end{tabular}

Source: own processing

For indicators, which increase spread over the years, we can clearly talk about that in terms of indicators, the wrong trend will be very difficult to stop and threatening for the company. ROE value in group D in 2013 is positive, because the average value of the group was strongly influenced by one company in a very bad situation with a negative equity value, which resulted in a positive value ROE. In some situation ROE is not good indicator for evaluation.

If we look at stability, we can evaluate individual indicators based on the significant changes in the relative values of the indicator between 2011 and 2013.

The relative change in the value of indicator $\mathrm{X}$ for Group A to $\mathrm{D}$ is calculated as

$$
\text { Delta } X=\operatorname{abs}\left(\left(X_{2013}-X_{2011}\right) / X_{2011}\right)
$$

The mean relative change of indicators for the whole group is calculated as the arithmetic mean of the relative deviation. Table 5 shows the average value of two years of stability in each group and the average relative value changes in all indicators between 2011 and 2013. 
Table 5. Delta value of two years of stability (2011-2013)

\begin{tabular}{|c|c|c|c|c|c|c|c|c|c|c|c|c|c|}
\hline G & OE/OR & ROA & ROS & ROE & VA/PE & I(VA) & FL & I(AD) & I(PE) & I(S) & I(TA) & mean & var \\
\hline A & 0.0 & 1.9 & 0.5 & 0.2 & 0.1 & 0.1 & 0.5 & 0.1 & 0.1 & 0.1 & 0.1 & 0.3 & 0.3 \\
\hline B & 0.0 & 0.1 & 0.2 & 0.2 & 1.1 & 1.4 & 0.0 & 0.0 & 0.1 & 0.0 & 0.1 & 0.3 & 0.2 \\
\hline C & 0.0 & 0.3 & 0.9 & 0.7 & 0.0 & 0.3 & 2.5 & 0.4 & 0.0 & 0.0 & 0.2 & 0.5 & 0.5 \\
\hline D & 0.0 & 6.5 & 2.6 & 1.0 & 0.0 & 0.0 & 1.6 & 2.7 & 0.0 & 0.1 & 0.0 & 1.3 & 3.7 \\
\hline
\end{tabular}

Source: own processing

We can clearly see that group A has a higher degree of stability results, but not significantly. Compared with group B, however, it has a higher standard deviation values of individual indicators. It shows that Group B is in its performance and stable development, while Group A is in some indicators very stable, but the other has a large deviation. We can say that Group A has more space to work with risk selection, which allows it to higher natural hedge of future performance.

\section{Acknowledgement}

The paper is processed as one of the outputs of the project "Methodology of Developing a Predictive Model of Sector and Company Performance in the Macroeconomic Context" registered by the Czech Science Foundation (GACR) under the registration no. 16-25536S.

\section{References}

AIA (2016). Automotive Industry association. Retriewed October 6, 2016, from http://www.autosap.cz/clenska-zakladna/\#vyrvoz

Czech National Bank. (2016). Government bond auctions and their results - history. Retriewed October 6, 2016, from http://www.cnb.cz/en/financial_markets/treasury_ securities_market/government_bonds/index.html

Czech Statistical Organization. (2016). Klasifikace ekonomických činností (CZ-NACE). Available online 10.10. 2016 on https://www.czso.cz/csu/czso/klasifikace_ekonomickych_ cinnosti_cz_nace

Damodaran, A. (2016). Cost of equity and capital (updateable). Retriewed October 6, 2016, from http://people.stern.nyu.edu/adamodar/New_Home_Page/data.html.

Finanční analýza podnikové sféry za rok 2014. (2015). Prague: Ministry of Industry and Trade CZ (MIT). Retriewed 6. 10. 2016, from http://www.mpo.cz/dokument157262.html

Foltýn, I. (2001). Competitiveness - a vague term or economically measurable indicator? Agricultural economics, 47 (4), pp. 165-168.

Klečka, J. (2013). Development of Value Productivity in Selected Industry Branches. In: T. Loster, T. Pavelka (eds.). The 7th International Days of Statistics and Economics. Conference Proceedings (pp. 611-620). Slaný (Czech Republic): Melandrium.

Klečka, Jiří, Čámská, Dagmar. (2013). Development of Value Productivity in Automotive Industry. World Academy of Science, Engineering and Technology [CD]. 2013, vol. 83, pp. $1160-1165$

Porter, M. E. (1996). What is Strategy? Harvard Business Review. 74 (6), pp. 61-81.

Scholleová, H., Čámská, D. (2015). Financial Factors Affecting Competitiveness. In: SOLIMAN, Khalid S. (ed.). Proceedings of The 25th International Business Information Association Conference. Innovation Vision 2020: From Regional Development Sustainability to Global Economic Growth. Amsterdam, IBIMA, pp. 1933-1942. 
Sturgeon, T., Van Biesebroeck, J., Gereffi, G. (2008). Value chains, networks and clusters: reframing the global automotive industry. Journal of economic geography, 8 (3), pp. 297-321. 